TECHNO

Vol.22, No.1, April 2021, Hal. 13 26

P-ISSN: 1410-8607, E-ISSN: 2579-9096

\title{
DAMPAK PERUBAHAN LANDUSE TERHADAP DEBIT PUNCAK BANJIR SUNGAI SERAYU HULU
}

\author{
Teguh Marhendi ${ }^{1}$, Ahmad Syamsul Munir ${ }^{2}$ \\ Program Studi S1 Teknik Sipil, Universitas Muhammadiyah Purwokerto \\ Fakultas Teknik dan Sains, Universitas Muhammadiyah Purwokerto
}

\section{Informasi Makalah}

Dikirim, 11 November 2020

Direvisi,

Diterima, 03 Maret 2021

\section{Kata Kunci:}

Puncak Banjir

Perubahan Landuse

DAS Serayu Hulu

\begin{abstract}
INTISARI
Peningkatan populasi yang cepat menghasilkan penambahan pembangunan penduduk dan infrastruktur yang dibutuhkan. Perkembangan ini akhirnya akan menghasilkan peningkatan permukaan kedap air sehingga kecepatan aliran di permukaan meningkat. Peningkatan kecepatan aliran selanjutnya dapat menyebabkan perubahan puncak limpasan. Penelitian ini dimaksudkan untuk mengetahui bagaimana kondisi perubahan penggunaan lahan di DAS Serayu Hulu dan debit puncak Sungai Serayu Hulu dititik kontrol Waduk Mrica Banjarnegara pada tahun 2009 - 2018 dan bagaimana prediksi perubahan penggunaan lahan di DAS Serayu Hulu dan debit puncak Sungai Serayu Hulu dititik kontrol Waduk Mrica Banjarnegara pada tahun 2019 2028. Analisis dilaksanakan menggunakan metode statistika dan archGIS 10.3. Hasil penelitian ini menunjukkan bahwa perubahan tataguna lahan daerah bervegetasi DAS Serayu Hulu tahun 2018 menempati luas 62.149,45 Ha dengan debit puncak pada tahun 2018 adalah 163,32 $\left(\mathrm{m}^{3} / \mathrm{dt}\right)$. Prediksi perubahan tataguna lahan daerah bervegetasi dengan debit puncak DAS Serayu Hulu selama 10 tahun di tahun 2028 sebesar 50.153,10 ha, dengan debit puncak sebesar 174,555 $\left(\mathrm{m}^{3} / \mathrm{dt}\right)$.
\end{abstract}

\section{Keyword:}

Peak Floods

Changes in Landuse

Serayu Hulu Watershed

\begin{abstract}
The rapid population increase results in additional population development and the infrastructure required. This development will eventually result in an increase in the watertightness of the surface so that the flow rate over the surface increases. A further increase in flow velocity can lead to a change in peak runoff. This research is intended to determine how the conditions of land use change in the Serayu Hulu watershed and the peak discharge of the Serayu Hulu River at the control point of the Mrica Banjarnegara Reservoir in 2009 - 2018 and how the prediction of changes in land use in the Upper Serayu Watershed and the peak discharge of the Upper Serayu River at the control point of the Mrica Reservoir Banjarnegara in 2019 - 2028. The analysis was carried out using statistical methods and archGIS 10.3. The results of this study indicate that the land use change in the vegetation area of the Serayu Hulu watershed in 2018 occupied an area of 62,149.45 hectares with the peak discharge in 2018 was $163.32(\mathrm{~m} 3 / \mathrm{s})$. Prediction of changes in land use in vegetated areas with peak discharge in the Serayu Hulu watershed for 10 years in 2028 of 50,153.10 ha, with a peak discharge of 174,555 (m3/ s).
\end{abstract}

\section{Korespondensi Penulis:}

Teguh Marhendi

Program Studi Teknik Sipil

Universitas Muhammadiyah Purwokerto

JL. Raya Dukuhwaluh Purwokerto, 53182

Email: teguhmarhendi@ump.ac.id, tmarhendi@gmail.com 


\section{PENDAHULUAN}

Salah satu sarana pendistribusian air kepada manusia adalah melalui sungai yang berawal dari hulu hingga bermuara ke hilir. Sungai tidak hanya terdapat pada daerah pedesaan dan pegunungan, namun juga pada daerah perkotaan. Manfaat sungai bagi kehidupan manusia memang sangat penting dan sangat vital, karena seluruh makhluk hidup yang ada di bumi juga membutuhkan sungai untuk keperluan sehari - hari, seperti penampung air, mencegah banjir, mengalirkan air ke hilir, pembangkit listrik, pusat ekosistem, mencari nafkah, dan lain sebagainya.

DAS Serayu Hulu merupakan satuan wilayah sungai yang terletak di bagian Selatan Jawa Tengah. DAS Serayu Hulu berada di Kabupaten Banjarnegara dan Wonosobo dan secara geografis terletak pada koordinat $07^{\circ} 05^{\prime}-07^{\circ} 4^{\prime}$ LS dan $108^{\circ} 56^{\prime}$ - $110^{\circ}$ 05' BT. Penggunaan lahan DAS Serayu Hulu secara umum terbagi menjadi sebelas jenis penggunaan lahan. Jenis penggunaan lahan didominasi oleh jenis penggunaan lahan kebun seluas 30,43\%. Penggunaan lahan yang lainnya meliputi air tawar $(0,80 \%)$, semak belukar $(9,84 \%)$, gedung $(0,04 \%)$, permukiman $(1,47 \%)$, rawa $(0,01 \%)$, rumput $(0,35 \%)$, sawah irigasi $(6,36 \%)$, sawah tadah hujan (13,32\%), dan tegalan/pertanian lahan kering (30,15\%). [1] [4] [5].

Peningkatan populasi yang cepat menghasilkan penambahan pembangunan penduduk dan infrastruktur yang dibutuhkan. Perkembangan ini akhirnya akan menghasilkan peningkatan permukaan kedap air sehingga kecepatan aliran di permukaan meningkat. Peningkatan kecepatan aliran selanjutnya dapat menyebabkan perubahan puncak limpahan [2] [4] [5].

Penelitian mengenai pengaruh perubahan pemanfaatan lahan hutan terhadap pengaturan aliran sungai biasanya dilakukan di hulu DAS (100 - $1.000 \mathrm{Ha})$ dan sering mempertimbangkan hanya perubahan tutupan vegetasi tunggal (misalnya dari hutan menjadi padang rumput) [3].

Banjir merupakan bagian dari siklus hidrologi yang terjadi karena debit air sungai yang tinggi dengan curah hujan yang tinggi hingga melampaui daya tampung saluran sungai lalu meluap ke daerah sekitarnya. Secara umum ada beberapa faktor-faktor yang menyebabkan terjadinya banjir, yaitu kondisi alam (letak geografis wilayah, kondisi topografi, geometri sungai dan sedimentasi), peristiwa alam (curah hujan dan lamanya hujan, pasang, arus balik dari sungai utama, pembendungan aliran sungai akibat longsor dan aktifitas manusia (pembudidayaan daerah). Adanya tekanan penduduk terhadap kebutuhan lahan baik untuk kegiatan pertanian, perumahan, industri, rekreasi, maupun kegiatan lain akan menyebabkan perubahan penggunaan lahan. Apabila kegiatan tersebut tidak dikelola dengan baik, maka akan menyebabkan kelebihan air (banjir) pada saat musim hujan dan kekeringan pada musim kemarau. Hal ini disebabkan karena perubahan penggunaan lahan yang tidak bijaksana (tidak disertai penanganan tindakan konservasi), sehingga hujan yang jatuh sebagian besar akan menjadi aliran permukaan (Run-Offo) [5] [6] [11].

Wilayah yang memiliki penggunaan lahan paling intensif bukan wilayah dengan tingkat kepadatan penduduk tertinggi maupun tingkat pertumbuhan populasi tercepat, melainkan wilayah yang memiliki persediaan keuangan yang lebih besar guna melakukan kegiatan-kegiatan di wilayahnya. Tingkat Kepadatan penduduk memiliki hubungan berbanding terbalik dengan tingkat pertambahan/penggundulan hutan karena kepadatan penduduk yang tinggi umumnya terdapat pada wilayah yang memiliki penggunaan lahan intensif. Sedangkan tingginya tingkat perambahan/penggundulan hutan menunjukan gejala awal suatu wilayah kian berkembang (eksploratif) [7].

Selanjutnya Arsyad (2006) dalam Pramono Anggit Aji (2018) menyatakan bahwa, perubahan penggunaan lahan memiliki dampak potensial besar terhadap lingkungan bio-fisik dan sosial ekonomi. Secara umum penggunaan lahan digolongkan ke dalam dua golongan, yaitu [4] [5]:

1. Penggunaan lahan pedesaan, secara umum dititikberatkan pada produksi pertanian, termasuk pengelolaan sumberdaya alam dan kehutanan.

2. Penggunaan perkotaan, secara umum dititik beratkan untuk tempat tinggal, pemusatan ekonomi, layanan jasa, dan pemerintahan.

Penelitian mengelompokkan penggunaan lahan menjadi tujuh kategori, masing - masing adalah hutan, semak/belukar, kebun campuran, pemukiman, sawah, tegalan, dan lahan terbuka. Pengertian masing-masing penggunaan lahan mengikuti pengertian yang umum dikenal dan biasa digunakan dalam klasifikasi penggunaan lahan. Harimurti (1999) dalam Pramono Anggit Aji (2018), memberikan definisi dan batasan yang jelas mengenai tipe-tipe penggunaan lahan di atas. Definisi hutan dinyatakan sebagai wilayah yang ditutupi oleh vegetasi pepohonan, baik alami maupun yang dikelola, dengan tajuk yang rimbun dan besar/lebat. Semak belukar merupakan hutan yang telah dirambah atau dibuka, merupakan area transisi dari hutan lebat menjadi kebun atau lahan pertanian, bisa berupa hutan dengan semak atau belukar dengan tajuk yang relatif kurang rimbun. Kebun campuran adalah daerah yang ditumbuhi vegetasi tahunan satu jenis maupun campuran baik dengan pola acak, maupun teratur sebagai pembatas tegalan. Pemukiman lebih identik dengan kombinasi antara jalan, bangunan, pekarangan, dan bangunan itu sendiri. Sawah merupakan daerah pertanian yang ditanami padi sebagai tanaman utama dengan rotasi tertentu yang biasanya diairi sejak saat penanaman hingga beberapa hari 
sebelum panen. Sedangkan tegalan merupakan daerah yang umumnya ditanami tanaman semusim, namun pada sebagian lahan tidak ditanami, dengan vegetasi yang umum dijumpai seperti padi gogo, singkong, jagung, kentang, kedelai, dan kacang tanah. Lahan terbuka merupakan daerah yang tidak ditemukan vegetasi berkayu, umumnya hanya jenis rerumputan maupun penggunaan lain akibat aktivitas manusia. Pengelompokan vegetasi tersebut juga tidak terlepas dari kemampuan lahan yang ditumbuhi atau dimanfaatkan tersebut dalam menyerap air hujan, disamping faktor-faktor fisik lain yang mampengaruhi berupa kemiringan lereng, jenis tanah menurut kepekaan erosi serta curah hujan [5].Dengan demikian maka apabila terjadi perubahan pada penggunaan lahan, maka akan mempengaruhi keseluruhan sistem ekologi termasuk hidrologi pada wilayah DAS tersebut. Dalam skala besar dampak perubahan tersebut adalah terjadinya gangguan perilaku air sungai, pada musim hujan debit air sungai akan meningkat tajam sementara pada musim kemarau debit air sangat rendah [5] [10].

Perubahan penggunaan lahan umumnya dapat diamati dengan menggunakan data-data spasial dari peta penggunaan lahan dan data-data penginderaan jauh (remote sensing data) seperti citra satelit, radar, dan foto udara sangat berguna dalam pengamatan perubahan penggunaan lahan. Perubahan penggunaan lahan (landuse change) meliputi pergeseran penggunaan lahan menuju penggunaan lahan yang berbeda (conversion) atau diversifikasi pada penggunaan lahan yang sudah ada. Secara umum perubahan penggunaan lahan akan mengubah: (a) karakteristik aliran sungai, (b) jumlah aliran permukaan, (c) sifat hidrologis daerah yang bersangkutan [8].

\section{METODE PENELITIAN}

\subsection{Lokasi Penelitian}

Penelitian dilaksanakan di DAS Serayu Hulu yang meliputi 2 wilayah yaitu, Kabupaten Banjarnegara dan Kabupaten Wonosobo Jawa Tengah.

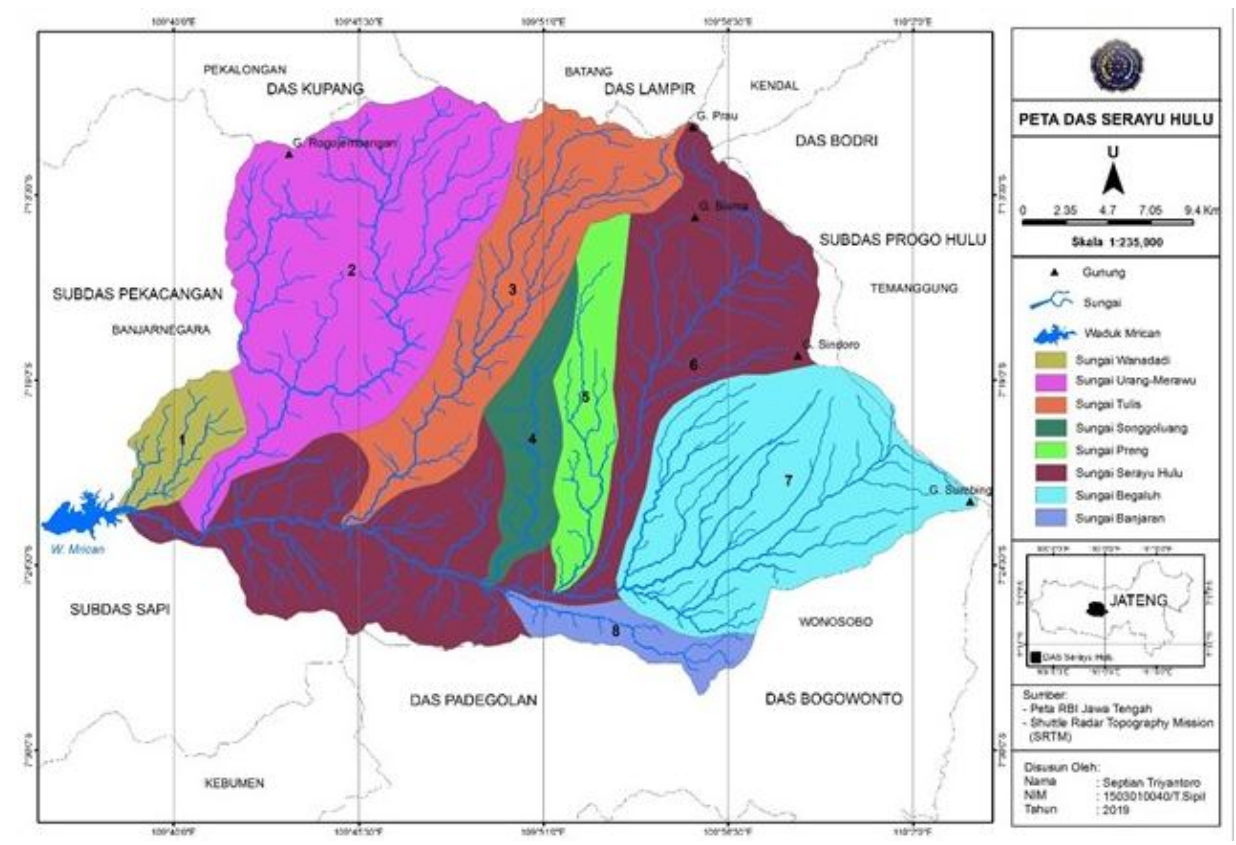

Gambar 1. Lokasi Penelitian 


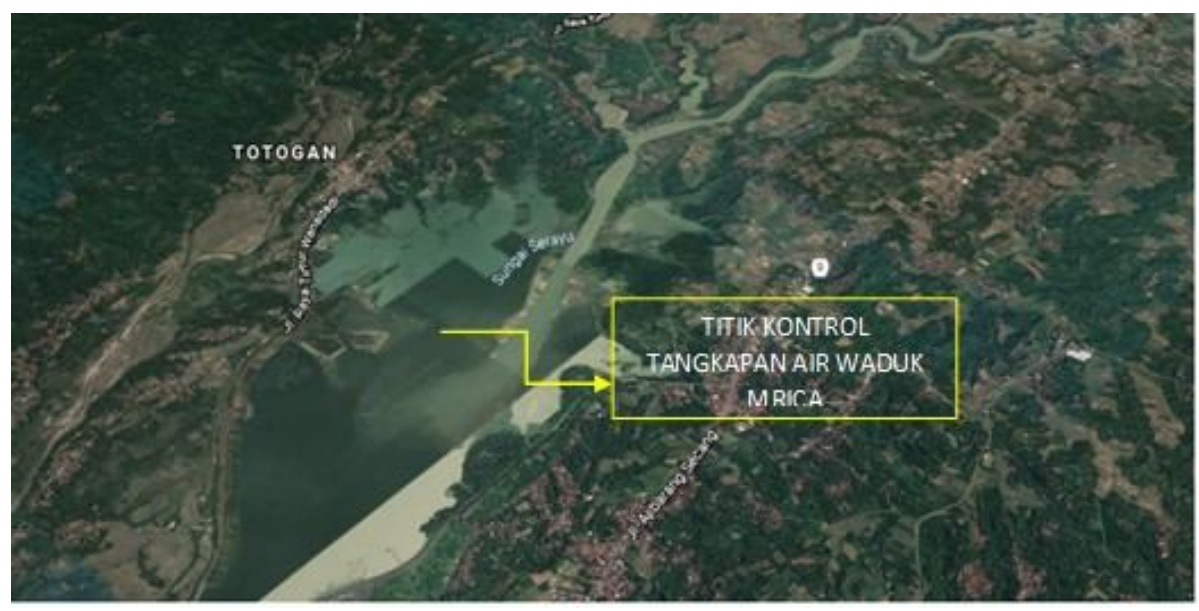

Gambar 2. Lokasi Titik Kontrol Waduk Mrica [9]

\subsection{Alat dan data penelitian}

Alat dan data penelitian yang digunakan untuk pengumpulan dan pengolahan data meliputi :

1. Software yang digunakan berupa Google Earth, dan ArcGIS.10.3.

2. Data Tataguna Lahan (land use) Kabupaten Banjarnegara dan Kabupaten Wonosobo tahun 2009 $-2018$

3. Data debit aliran Sungai Serayu Hulu di titik kontrol Waduk Mrica tahun $2009-2018$.

4. Data Hujan Selama 20 Tahun (1998-2018)

\subsection{Prosedur dan Analisa Data Penelitian}

Penelitian ini dilakukan melalui dua tahap : pertama, menganalisis perubahan penggunaan lahan (land use) tahun 2009 - 2018 dengan menggunakan Google Earth, ArcGIS.10.3, dan untuk memprediksi atau mengasumsikan perubahan penggunaan lahan tahun 2019-2028 menggunakan model persamaan logarithmic. Kedua, untuk memprediksi debit aliran sungai Serayu Hulu di titik kontrol Waduk Mrica tahun 2019 - 2028 menggunakan metode analisis regresi linear sederhana. Secara terinci dua tahap tersebut diuraikan sebagai berikut :

\subsection{Analisa Perubahan Penggunaan Lahan}

Pengklasifikasikan penggunaan lahan pada DAS Serayu Hulu dalam penelitian ini, digunakan data citra yang ditujukan untuk mendapatkan informasi tentang penggunaan lahan aktual dari tahun penelitian, yaitu peta dan data penggunaan lahan tahun 2009 - 2018 yang didapat dari Google Earth, BAPPEDA Kabupaten Banjarnegara dengan Kabupaten Wonosobo dan DPU Banjarnegara. Data yang ada selanjutnya dilakukan proses pengklasifikasian dan perhitungan dengan menggunakan Software ArcGIS.10.3 dan Microsoft Excel 2013 guna untuk mendapatkan pola atau arah perubahan dan angka perubahan penggunaan lahan. Selanjutnya untuk memprediksi atau mengasumsikan angka perubahan penggunaan lahan pada tahun 2009 - 2018 guna untuk memprediksi debit pada tahun 2019 - 2028 maka digunakan persamaan logarithmic.

\subsection{Analisa Hidrologi dan Prediksi Perubahan Debit Puncak}

Analisis hidrologi dalam penelitian ini ditujukan untuk mendapatkan angka prediksi debit puncak di titik kontrol Waduk Mrica Banjarnegara pada tahun 2019 - 2028. Data yang dibutuhkan dalam analisis hidrologi ini adalah data penggunaan lahan untuk kawasan daerah bervegetasi di DAS Serayu Hulu dan data rekaman debit aliran sungai serayu di titik kontrol Waduk Mrica Banjarnegara. Data - data yang telah diperoleh, selanjutnya dianalisis untuk mencari debit aliran sungai serayu di titik kontrol bendung gerak serayu pada tahun 2019 - 2028 [8]. Langkah - langkah dalam analisis hidrologi adalah sebagai berikut :

1. Mencari pengaruh perubahan lahan terhadap debit puncak Proses ini dilakukan guna untuk mencari tingkat hubungan atau pengaruh antara variabel X (independent) terhadap variabel Y (dependent). Penelitian ini menggunakan analysis regression pada Microsoft Excel 2013 untuk mendapatkan nilai $\mathrm{r}$ (korelasi).

2. Analisis regresi untuk prediksi debit

Langkah - langkah dalam menghitung prediksi debit puncak sungai Serayu Hulu di titik kontrol Waduk Mrica tahun 2019 - 2028 digunakan metode analisis regresi linear sederhana.

3. Melakukan prediksi perubahan debit puncak menggunakan persamaan yang sudah dibuat. 


\section{HASIL DAN PEMBAHASAN}

\subsection{Analisa Perubahan Penggunaan Lahan}

Luas DAS Serayu Hulu sebesar 97.783,87 ha atau 977,84 km², memiliki bentuk penggunaan lahan yang beranekaragam dalam hal jenis, luasan dan sebarannya. Keanekaragaman penggunaan lahan dalam penelitian ini dibedakan menjadi dua (2) macam, yaitu penggunaan lahan daerah bervegetasi untuk hutan, perkebunan dan semak belukar. Sedangkan daerah non vegetasi untuk persawahan, tegalan, ladang, gedung, bangunan industri, pemukiman dan air tawar. Berikut pada Tabel 1 dan Gambar 3 merupakan gambaran perubahan penggunaan lahan (land use) DAS Serayu Hulu dari tahun 2009 sampai dengan 2018.

Tabel 1. Penggunaan Lahan DAS Serayu Hulu 2009 - 2018

\begin{tabular}{ccrr}
\hline No. & Tahun & $\begin{array}{c}\text { Daerah Bervegetasi } \\
\text { (Ha) }\end{array}$ & $\begin{array}{c}\text { Daerah Non Vegetasi } \\
\text { (Ha) }\end{array}$ \\
\hline 1. & 2009 & $72.686,52$ & $25.097,34$ \\
2. & 2010 & $72.686,52$ & $25.097,34$ \\
3. & 2011 & $72.686,52$ & $25.097,34$ \\
4. & 2012 & $72.686,52$ & $25.097,34$ \\
5. & 2013 & $72.686,52$ & $25.097,34$ \\
6. & 2014 & $72.686,52$ & $25.097,34$ \\
7. & 2015 & $72.686,52$ & $25.097,34$ \\
8. & 2016 & $62.149,45$ & $35.634,43$ \\
9. & 2017 & $62.149,45$ & $35.634,43$ \\
10. & 2018 & $62.149,45$ & $35.634,43$
\end{tabular}

Sumber: BAPPEDA Wonosobo dan DPU Banjarnegara, 2018

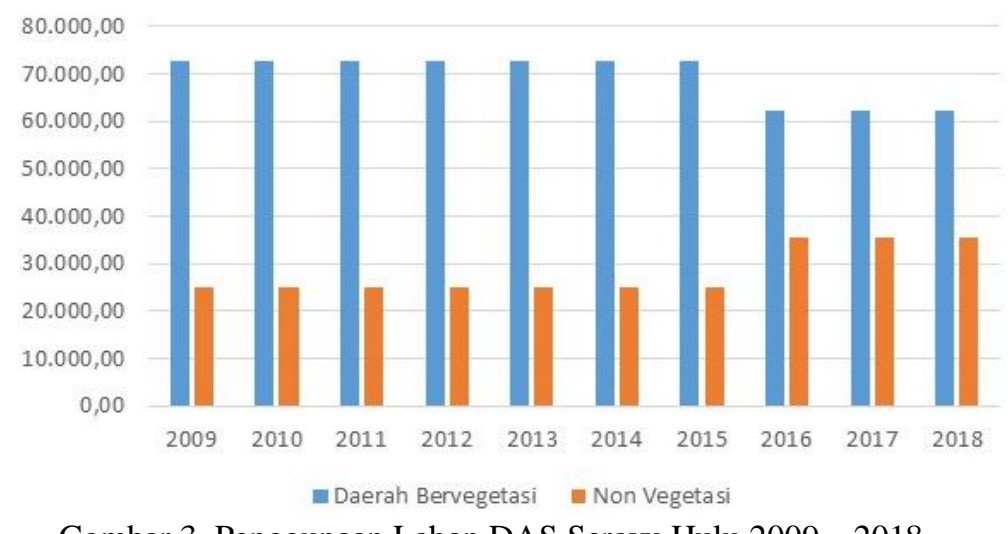

Gambar 3. Penggunaan Lahan DAS Serayu Hulu 2009 - 2018

\subsection{Penggunaan Lahan DAS Serayu Hulu Tahun 2009}

Berdasarkan interpretasi foto udara tahun 2009 maka dapat diketahui jenis - jenis penggunaan lahan yang terdapat di DAS Serayu Hulu. 


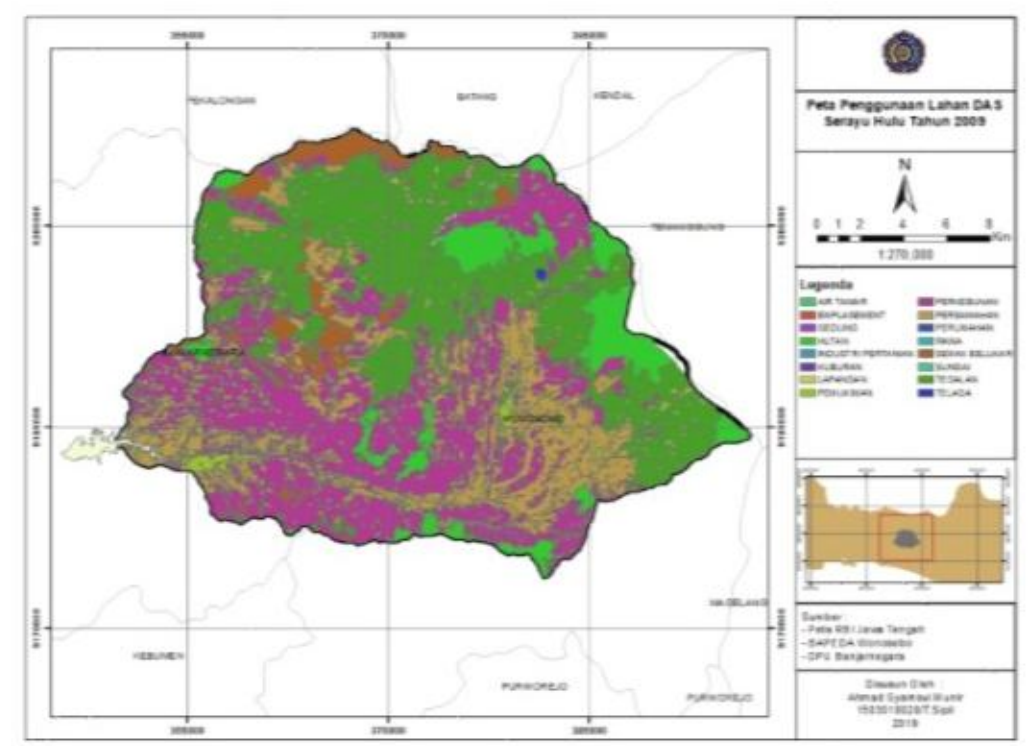

Gambar 4. Peta Penggunaan Lahan DAS Serayu Hulu Tahun 2009

Tabel 2. Penggunaan Lahan Bervegetasi DAS Serayu Hulu 2009

\begin{tabular}{|c|c|c|c|c|}
\hline \multirow[b]{2}{*}{ No } & \multirow{2}{*}{$\begin{array}{c}\text { Penggunaan Lahan } \\
\text { Bervegetasi }\end{array}$} & \multicolumn{3}{|c|}{ Luas } \\
\hline & & Ha & $\mathbf{K m}^{2}$ & $\%$ \\
\hline 1. & Hutan & $8.302,00$ & 83,02 & 8,49 \\
\hline 2. & Perkebunan & $29.701,36$ & 297,01 & 30,37 \\
\hline 3. & Semak Belukar & $4.682,41$ & 46,82 & 4,79 \\
\hline 4. & Tegalan & $30.000,75$ & 300,01 & 30,68 \\
\hline & Jumlah & $72.686,52$ & 726,87 & 74,33 \\
\hline
\end{tabular}

Tabel 3. Penggunaan Lahan Non Vegetasi DAS Serayu Hulu 2009

\begin{tabular}{ccrrr}
\hline & Penggunaan Lahan & \multicolumn{3}{c}{ Luas } \\
\cline { 3 - 5 } No & Non Vegetasi & Ha & Km $^{2}$ & \% \\
\hline 1. & Persawahan & $17.148,79$ & 171,49 & 17,54 \\
2. & Industri Pertanian & 10,68 & 0,11 & 0,01 \\
3. & Permukiman & $7.132,51$ & 71,33 & 7,29 \\
\hline 4. & Lahan Terbuka & 47,04 & 0,47 & 0,05 \\
5. & Gedung & 12,23 & 0,12 & 0,01 \\
6. & Lapangan & 7,82 & 0,08 & 0,008 \\
7. & TPU & 12,01 & 0,12 & 0,01 \\
8. & Rawa & 4,13 & 0,04 & 0,004 \\
9. & Sungai & 199,87 & 1,99 & 0,20 \\
10. & Air Tawar & 442,46 & 4,42 & 0,45
\end{tabular}




\begin{tabular}{rrrr} 
11. Telaga & 79,80 & 0,79 & 0,08 \\
\hline Jumlah & $25.097,34$ & 250,97 & 25,67
\end{tabular}

Sumber : Hasil Perhitungan Digitasi Arcgis Tahun 2009

Berdasarkan peta dan data penggunaan lahan DAS Serayu Hulu tahun 2009 (Gambar 4 dan Tabel 2 dan 3.) dapat diketahui bahwa jenis penggunaan lahan di DAS Serayu Hulu tahun 2009 - 2015 terdiri dari Hutan, Perkebunan, Semak belukar, Persawahan, Industei pertanian, Tegalan, Permukiman, Lahan terbuka, Gedung, TPU, Lapangan, Rawa, Sungai, Air tawar dan Telaga. Dengan penggunaan lahan terbesar adalah Tegalan dengan luas $300,01 \mathrm{~km}^{2}$ atau $30,68 \%$ dari total luasan lahan, dari tabel diatas maka dapat dijelaskan sebagai berikut :

a. Hutan

Secara umum hutan yang berada di DAS Serayu Hulu pada tahun 2009 merupakan hutan sejenis dan hutan lindung. Hutan menempati lahan seluas $83,02 \mathrm{~km}^{2}$ atau $8,49 \%$ dari total luasan lahan. Kondisi hutan mempunyai tajuk yang baik, dan berfungsi sebagai daerah resapan air.

b. Tegalan/Ladang Jenis penggunaan lahan ladang di DAS Serayu Hulu pada tahun 2009 menempati wilayah terluas pertama $300,01 \mathrm{~km}^{2}$ atau $30,68 \%$ dari total luasan lahan.

c. Perkebunan

Perkebunan merupakan areal tanaman holtikultura dan tanaman tahunan/keras yang dimiliki oleh penduduk atau perusahaan negara/swasta. Luas penggunaan lahan kebun merupakan jenis penggunaan terluas kedua di DAS Serayu Hulu pada tahun 2009 yang menempati lahan seluas 297,01 $\mathrm{km}^{2}$ atau $30,37 \%$ dari total luasan lahan.

d. Semak Belukar Jenis penggunaan lahan semak belukar di DAS Serayu Hulu pada tahun 2009 - 2015 menempati wilayah seluas $46,82 \mathrm{~km}^{2}$ atau $4,79 \%$ dari total luasan lahan.

e. Persawahan

Persawahan di DAS Serayu Hulu pada tahun 2009 - 2015 dibedakan menjadi 2 jenis yaitu sawah irigasi dan sawah tadah hujan. Total sawah menempati lahan seluas $171,49 \mathrm{~km}^{2}$ atau $17,54 \%$ dari total luasan lahan.

f. Industri Pertanian

Penggunaan lahan untuk industri pertanian di DAS Serayu Hulu pada tahun 2009 - 2015 menempati wilayah seluas $0,11 \mathrm{~km}^{2}$ atau $0,01 \%$ dari total luasan lahan.

g. Permukiman

Permukiman menempati lahan seluas $71,33 \mathrm{~km}^{2}$ atau 7,2\% dari total luasan lahan di DAS Serayu Hulu pada tahun 2009 - 2015. dalam penulisan ini ditambahkan gedung menempati lahan seluas $0,12 \mathrm{~km}^{2}$ atau $0,01 \%$, lahan terbuka menempati lahan seluas $0,47 \mathrm{~km}^{2}$ atau $0,05 \%$, TPU menempati lahan seluas $0,12 \mathrm{~km}^{2}$ atau $0,01 \%$ dan lapangan menempati lahan seluas $0,08 \mathrm{~km}^{2}$ atau $0,008 \%$ dari total luasan lahan.

\subsection{Penggunaan Lahan DAS Serayu Hulu Tahun 2018}

Berdasarkan interpretasi foto udara tahun 2018 maka dapat diketahui jenis - jenis penggunaan lahan yang terdapat di DAS Serayu Hulu.

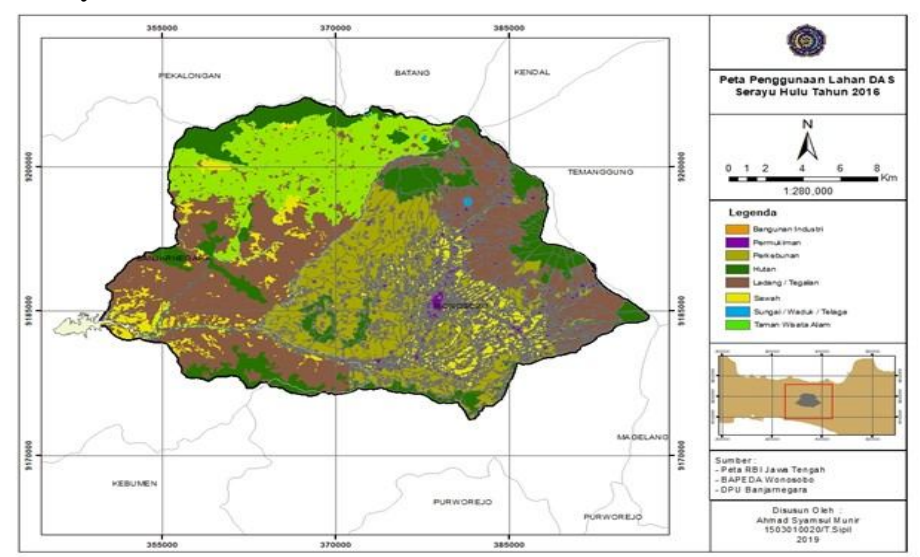

Gambar 5 Peta Penggunaan Lahan di DAS Serayu Hulu Tahun 2018 


\begin{tabular}{|c|c|c|c|c|}
\hline \multicolumn{5}{|c|}{ Tabel 4 Penggunaan Lahan Bervegetasi DAS Serayu 2018} \\
\hline \multirow[b]{2}{*}{ No } & \multirow{2}{*}{$\begin{array}{c}\text { Penggunaan Lahan } \\
\text { Bervegetasi }\end{array}$} & \multicolumn{3}{|c|}{ Luas } \\
\hline & & Ha & $\mathbf{K m}^{2}$ & $\%$ \\
\hline 1. & Hutan & $14.097,25$ & 140,97 & 14,44 \\
\hline 2. & Kebun Campuran & 3661609 & 366,17 & 37,44 \\
\hline \multirow{2}{*}{3.} & \multirow{2}{*}{ Tegalan } & & & 11,69 \\
\hline & & $11.435,21$ & 114,35 & \\
\hline \multicolumn{2}{|r|}{ Jumlah } & $62.149,45$ & 621,49 & 63,56 \\
\hline \multicolumn{5}{|c|}{ Tabel 5 Penggunaan Lahan Non Vegetasi DAS Serayu 2018} \\
\hline \multirow[b]{2}{*}{ No } & \multirow{2}{*}{$\begin{array}{c}\text { Penggunaan } \\
\text { Lahan Non } \\
\text { Vegetasi }\end{array}$} & \multicolumn{3}{|c|}{ Luas } \\
\hline & & Ha & $\mathbf{K m}^{2}$ & $\%$ \\
\hline 1. & Ladang & $16.401,92$ & 164,02 & 16,77 \\
\hline \multirow[t]{2}{*}{2.} & \multirow[t]{2}{*}{ Persawahan } & 1102704 & \multirow{2}{*}{110,23} & 11,27 \\
\hline & & $11.022,94$ & & \\
\hline 3. & Permukiman & $7.366,38$ & 73,66 & 7,53 \\
\hline 4. & Bangunan Industri & 31.86 & 0,32 & 0,03 \\
\hline \multirow[t]{2}{*}{5.} & \multirow[t]{2}{*}{ Lahan Terbuka } & 2205 & \multirow{2}{*}{0,23} & 0,02 \\
\hline & & 22,93 & & \\
\hline 6. & Sungai & 682,43 & 6,82 & 0,70 \\
\hline 7. & Telaga & 105,95 & & 0,11 \\
\hline & & & 1,06 & \\
\hline & Jumlah & $35.634,43$ & 356,35 & 36,4 \\
\hline
\end{tabular}

Sumber : Hasil Perhitungan Digitasi Foto Udara Tahun 2016

Berdasarkan peta dan data penggunaan lahan DAS Serayu Hulu (Gambar 5 dan Tabel 4 dan 5) dapat diketahui bahwa jenis penggunaan lahan di DAS Serayu Hulu 2016 - 2018 terdiri dari hutan, kebun campuran, ladang, tegalan, persawahan, pemukiman, bangunan industri, lahan terbuka, sungai dan telaga. Dengan penggunaan lahan terbesar adalah kebun campuran dengan luas $366,17 \mathrm{~km}^{2}$ atau $37,44 \%$ dari total luasan lahan, dari tabel diatas maka dapat dijelaskan sebagai berikut :
a. Sawah
Lahan persawahan di DAS Serayu Hulu pada tahun 2016 - 2018 menempati lahan seluas 110,23 km² atau $11,27 \%$ dari total luasan lahan dan sebagian besar merupakan sawah irigasi.
b. Hutan
Hutan yang berada di DAS Serayu Hulu pada tahun 2016 - 2018 terdiri dari hutan lindung, hutan rakyat dan hutan produksi. Hutan di DAS Serayu Hulu pada tahun 2016 - 2018 memiliki total luasan $140,97 \mathrm{~km}^{2}$ atau $14,44 \%$ dari total luasan lahan.
c. Kebun Campuran
Perkebunan merupakan areal tanaman holtikultura dan tanaman tahunan/keras yang dimiliki oleh penduduk atau perusahaan negara/swasta. Luas penggunaan lahan kebun campuran merupakan jenis penggunaan terluas di DAS Serayu Hulu pada tahun 2016 - 2018 yang menempati lahan seluas 366,17 $\mathrm{km}^{2}$ atau $37,44 \%$ dari total luasan lahan.
d. Ladang
Jenis penggunaan lahan ladang di DAS Serayu Hulu pada tahun 2016 - 2018 menempati wilayah seluas $164,02 \mathrm{~km}^{2}$ atau $16,77 \%$ dari total luasan lahan. Dalam penulisan ini ditambahkan jenis penggunaan lahan tegalan yang menempati wilayah seluas $114,35 \mathrm{~km}^{2}$ atau $11,69 \%$ dan lahan terbuka seluas $0,23 \mathrm{~km}^{2}$ atau $0,02 \%$ dari total luasan lahan.
e. Permukiman 
Permukiman menempati lahan seluas $73,66 \mathrm{~km}^{2}$ atau 7,53\% dari total luasan lahan DAS Serayu Hulu tahun 2016 - 2018. Permukiman meliputi bangunan industri 0,32 $\mathrm{km}^{2}$ atau $0,03 \%$ dari total luasan lahan.

f. Air Tawar

Sungai menempati lahan seluas $6,82 \mathrm{~km}^{2}$ atau $0,70 \%$ dan telaga memiliki lahan seluas $1,06 \mathrm{~km}^{2}$ atau $0,11 \%$ dari total luasan lahan.

\subsection{Analisis Daerah Bervegetasi 10 Tahun Terakhir}

Analisis daerah bervegetasi 10 tahun terakhir didapatkan dari data penggunaan lahan DAS Serayu Hulu tahun 2009 dan 2016 yang didapat dari BAPPEDA Wonosobo dan DPU Banjarnegara. Untuk data penggunaan lahan pada tahun yang kosong menyesuaikan dengan data tahun yang ada. Berikut Tabel daerah bervegetasi dari data tahun 2009 sampai tahun 2018.

\begin{tabular}{cc} 
Tabel 6 Daerah Bervegetasi DAS Serayu Hulu \\
\hline Tahun & Daerah Bervegetasi (Ha) \\
\hline 2009 & $72.686,52$ \\
2010 & $72.686,52$ \\
2011 & $72.686,52$ \\
2012 & $72.686,52$ \\
2013 & $72.686,52$ \\
2014 & $72.686,52$ \\
2015 & $62.149,45$ \\
2016 & $62.149,45$ \\
2017 & $62.149,45$
\end{tabular}

Sumber: Analisis Data, 2020

\subsection{Prediksi Penggunaan Lahan Bervegetasi}

Prediksi penggunaan lahan bervegetasi dilakukan selama 10 tahun dimulai dari waktu penelitian yaitu tahun 2019 sampai dengan tahun 2028. Dari hasil perhitungan excel 2013 didapat persamaan logarithmic : Y $=-2.699 .369,3829 \times \ln (X)+20.605 .325,5576$ atau bisa dilihat pada Gambar 6 .

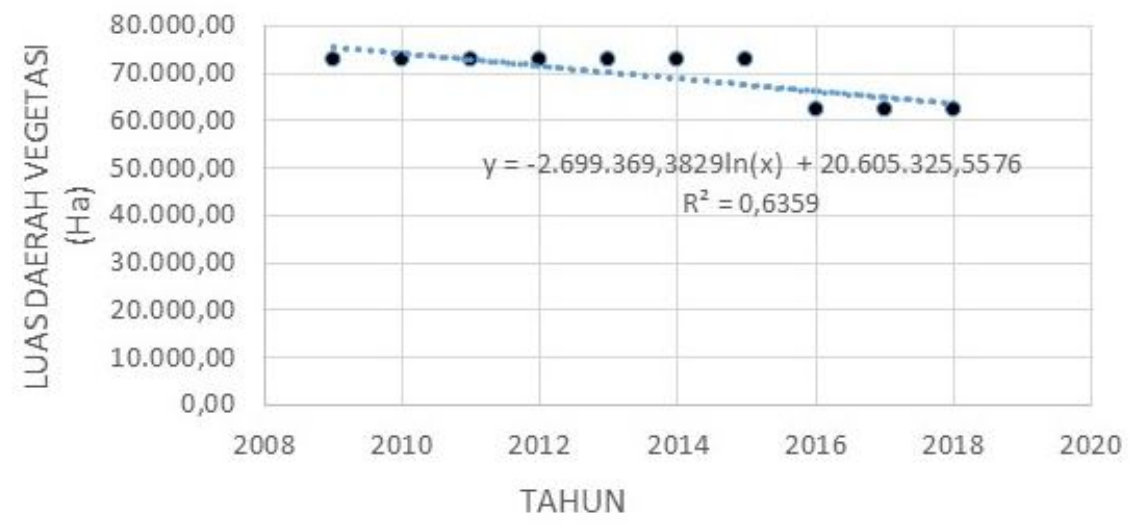

Gambar 6 Grafik perubahan landuse tahun 2008-2018 di das serayu hulu

Berdasarkan Gambar 6, didapat hasil prediksi penggunaan lahan bervegetasi selama 10 tahun adalah seperti Tabel 7 dibawah ini. 
Tabel 7 Hasil Prediksi Luas Daerah Bervegetasi DAS serayu Hulu

\begin{tabular}{ccr}
\hline No. & Tahun & $\begin{array}{c}\text { Daerah Bervegetasi } \\
(\mathrm{Ha})\end{array}$ \\
\hline 1 & 2019 & $62.159,21$ \\
2 & 2020 & $60.822,56$ \\
3 & 2021 & $59.486,57$ \\
4 & 2022 & $58.151,24$ \\
5 & 2023 & $56.816,57$ \\
6 & 2024 & $55.482,56$ \\
7 & 2025 & $54.149,21$ \\
8 & 2026 & $52.816,51$ \\
9 & 2027 & $51.484,48$ \\
10 & 2028 & $50.153,1$ \\
\hline
\end{tabular}

Sumber : Analisis Data,2020

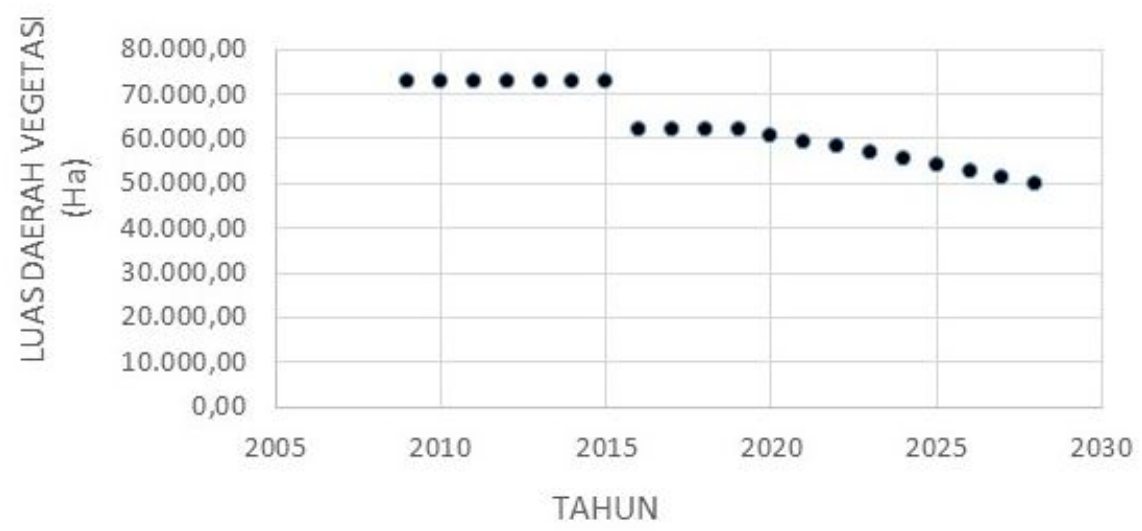

Gambar 7 Prediksi perubahan luas landuse DAS Serayu Hulu Tahun 2019-2028

\subsection{Analisis Rata-Rata Debit Puncak 10 Tahun Terakhir}

Analisis rata-rata debit puncak 10 tahun terakhir didapatkan dari nilai tertinggi (angka maximum) data debit bulanan setiap tahun mulai dari tahun 2009 sampai 2018. Berikut Tabel rata-rata debit puncak dari data tahun 2009 sampai tahun 2018 yang diperoleh dari PT. Indonesia Power.

Tabel 8 Rata-Rata Debit Puncak di Titik Kontrol Waduk Mrica

\begin{tabular}{lr}
\hline Tahun & Debit Puncak $\left(\mathrm{m}^{3} / d t\right)$ \\
\hline 2009 & 173,79 \\
2010 & 154,69 \\
2011 & 140,25 \\
2012 & 157,80 \\
2013 & 142,75 \\
2014 & 187,10 \\
2015 & 146,70 \\
2016 & 175,31 \\
2017 & 164,06 \\
2018 & 163,32 \\
\hline
\end{tabular}

Sumber: PT. Indonesia Power Banjarnegara, 2020 


\subsection{Prediksi Debit Puncak}

Prediksi debit puncak dilakukan selama 10 tahun dimulai dari waktu penelitian yaitu tahun 2019 sampai dengan tahun 2028. Untuk melakukan prediksi maka perlu dicari nilai $\mathrm{X}_{\mathrm{P}}$ atau variabel penduga (predictor/independent). Penulis dalam penelitian ini menggunakan model persamaan logarithmic untuk menentukan nilai $X_{P}$ atau variabel penduga. Dari hasil perhitungan excel 2013 didapat persamaan logarithmic : $Y=1923,3 \times \ln (X)+14471$ atau bisa dilihat pada Gambar 8.

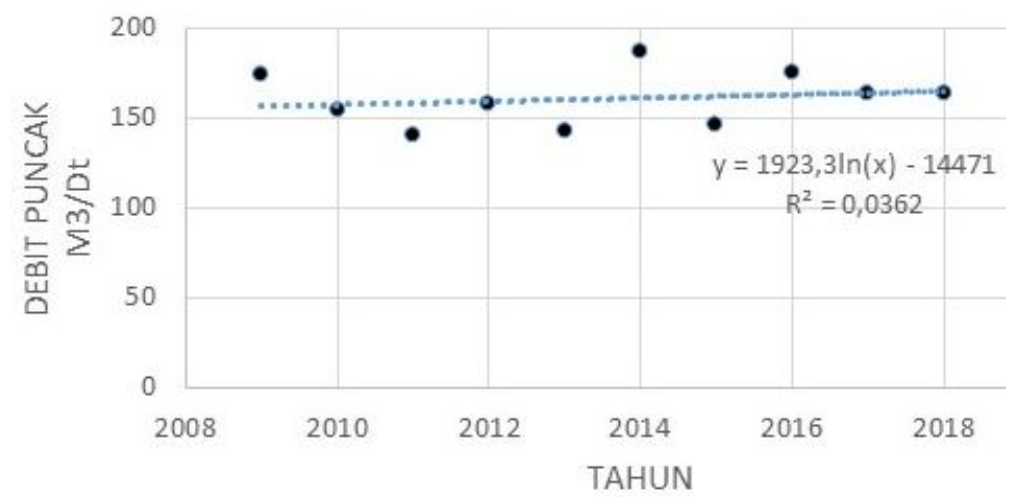

Gambar 8 Perubahan besaran debit Sungai Serayu di titik kontrol Waduk Mrica tahun 2009-2018

Berdasarkan Gambar 8, didapat hasil debit puncak selama 10 tahun adalah seperti Tabel 9 dibawah ini. Tabel 9 Hasil Prediksi Debit Puncak DAS serayu Hulu

\begin{tabular}{ccc}
\hline No. & Tahun & Debit Puncak m3/det \\
\hline 1 & 2019 & 166,000 \\
2 & 2020 & 166,953 \\
3 & 2021 & 167,905 \\
4 & 2022 & 168,856 \\
5 & 2023 & 169,807 \\
6 & 2024 & 170,757 \\
7 & 2025 & 171,707 \\
8 & 2026 & 172,657 \\
9 & 2027 & 173,606 \\
10 & 2028 & 174,555 \\
\hline
\end{tabular}

Sumber : Analisis 2020

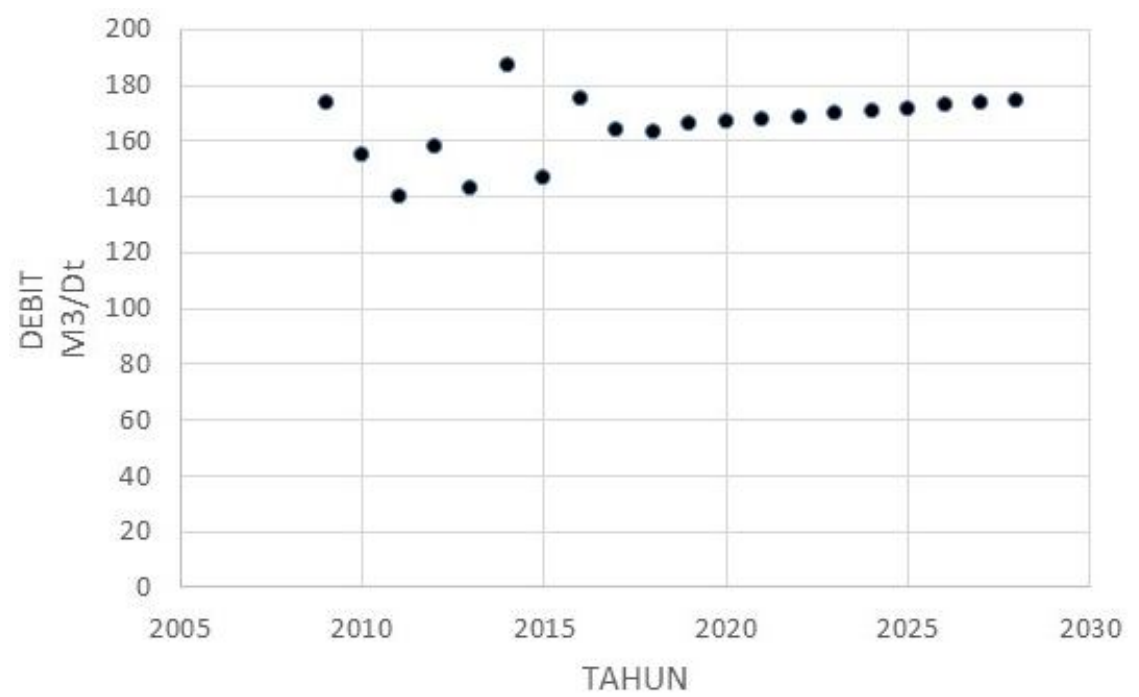

Gambar. 9 Prediksi Perubahan Debit Puncak Sungai Serayu di titik kontrol Waduk Mrica tahun 2019-2028 


\subsection{Analisis Perubahan Penggunaan Lahan Bervegetasi Terhadap Perubahan Puncak Banjir DAS} Serayu Hulu.

Berdasarkan Tabel 9 dan Gambar 9 terlihat bahwa angka debit puncak hasil prediksi dari tahun 2019 sampai dengan tahun 2028 mempunyai kecenderungan naik setiap tahunnya. Kenaikan debit prediksi di titik kontrol Waduk Mrica Banjarnegara disebabkan oleh terjadinya perubahan penggunaan lahan daerah bervegetasi di DAS Serayu Hulu.

Tabel 10 Prediksi debit puncak dan luasan daerah bervegetasi di DAS Serayu Hulu tahun 2019-2028

\begin{tabular}{rrr} 
Tahun & $\begin{array}{c}\text { Debit } \\
(\mathrm{m} 3 / \mathrm{dt})\end{array}$ & $\begin{array}{c}\text { Luas Daerah Bervegetasi } \\
(\text { Ha })\end{array}$ \\
\hline 2009 & 173,79 & $72.686,52$ \\
2010 & 154,69 & $72.686,52$ \\
2011 & 140,25 & $72.686,52$ \\
2012 & 157,798 & $72.686,52$ \\
2013 & 142,75 & $72.686,52$ \\
2014 & 187,1 & $72.686,52$ \\
2015 & 146,7 & $72.686,52$ \\
2016 & 175,31 & $62.149,45$ \\
2017 & 164,06 & $62.149,45$ \\
2018 & 163,32 & $62.149,45$ \\
2019 & 166,000 & $62.159,21$ \\
2020 & 166,953 & $60.822,56$ \\
2021 & 167,905 & $59.486,57$ \\
2022 & 168,856 & $58.151,24$ \\
2023 & 169,807 & $56.816,57$ \\
2024 & 170,757 & $55.482,56$ \\
2025 & 171,707 & $54.149,21$ \\
2026 & 172,657 & $52.816,51$ \\
2027 & 173,606 & $51.484,48$ \\
2028 & 174,555 & $50.153,10$ \\
\hline & &
\end{tabular}

Sumber : Analisis Data, 2020

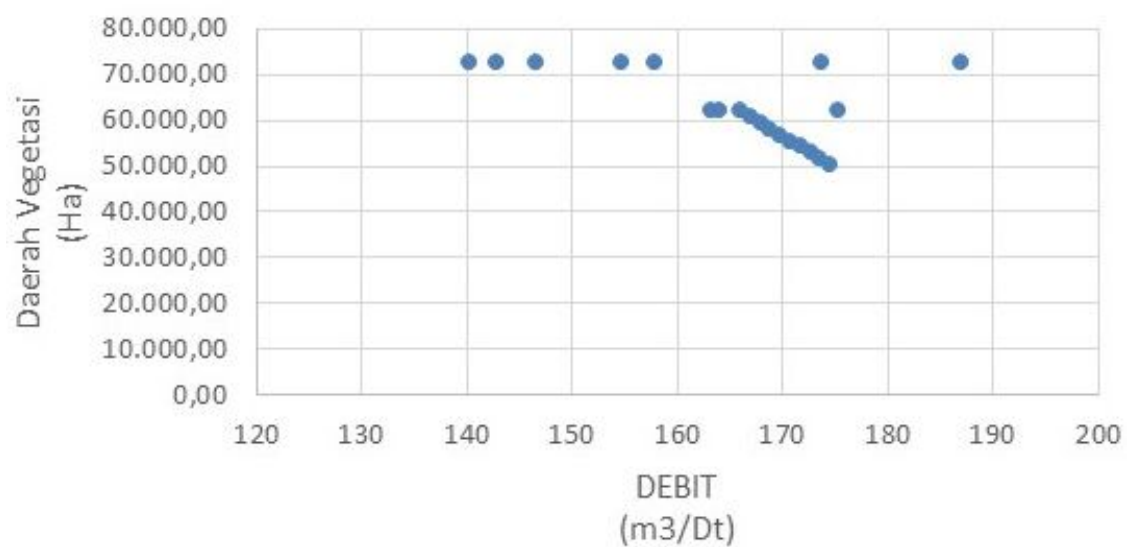

Gambar 10 Hubungan perubahan debit puncak vs perubahan penggunaan lahan (vegetasi) di DAS Serayu Hulu 2009-2028 


\section{KESIMPULAN}

Berdasarkan hasil penelitian dapat ditarik beberapa kesimpulan sebagai berikut :

1. Perubahan tataguna lahan daerah bervegetasi DAS Serayu Hulu tahun 2018 menempati luas 62.149,45 Ha dengan debit puncak pada tahun 2018 adalah 163,32 $\left(\mathrm{m}^{3} / \mathrm{dt}\right)$.

2. Prediksi perubahan tataguna lahan daerah bervegetasi dengan debit puncak DAS Serayu Hulu selama 10 tahun sebagai berikut :

a. Daerah bervegetasi tahun 2019 sebesar $62.159,21$ ha, dengan debit puncak sebesar $166,000\left(\mathrm{~m}^{3} / \mathrm{dt}\right)$.

b. Daerah bervegetasi tahun 2020 sebesar $60.822,56$ ha, dengan debit puncak sebesar $166,953\left(\mathrm{~m}^{3} / d t\right)$.

c. Daerah bervegetasi tahun 2021 sebesar $59.486,57$ ha, dengan debit puncak sebesar $167,905\left(\mathrm{~m}^{3} / d t\right)$.

d. Daerah bervegetasi tahun 2022 sebesar 58.151,24 ha, dengan debit puncak sebesar 168,856 $\left(\mathrm{m}^{3} / \mathrm{dt}\right)$.

e. Daerah bervegetasi tahun 2023 sebesar $56.816,57$ ha, dengan debit puncak sebesar $169,807\left(\mathrm{~m}^{3} / \mathrm{dt}\right)$.

f. Daerah bervegetasi tahun 2024 sebesar 55.482,56 ha, dengan debit puncak sebesar 170,757 $\left(\mathrm{m}^{3} / \mathrm{dt}\right)$.

g. Daerah bervegetasi tahun 2025 sebesar $54.149,21$ ha, dengan debit puncak sebesar 171,707 $\left(\mathrm{m}^{3} / \mathrm{dt}\right)$.

h. Daerah bervegetasi tahun 2026 sebesar 52.816,51 ha, dengan debit puncak sebesar 172,657 $\left(\mathrm{m}^{3} / \mathrm{dt}\right)$.

i. Daerah bervegetasi tahun 2027 sebesar 51.484,48 ha, dengan debit puncak sebesar 173,606 $\left(\mathrm{m}^{3} / \mathrm{dt}\right)$.

j. Daerah bervegetasi tahun 2028 sebesar 50.153,10 ha, dengan debit puncak sebesar 174,555 $\left(\mathrm{m}^{3} / \mathrm{dt}\right)$.

\section{UCAPAN TERIMAKASIH}

1. PT Uni Indonesia Power UBP Waduk Mrica

2. Balai Besar Wilayah Sungai Progo-Opak-Serang

3. Balai Pengembangan Sumber Daya Air Serayu Citanduy

4. Dinas ESDM Kabupaten Banyumas.

\section{DAFTAR PUSTAKA}

[1] Christanto, Nugroho, Setiawan M Anggri, Nurkholis Afid, Istiqomah Saidah, Sartohadi Junun, Hadi M Pramono, 2018, Analisis Laju Sedimen Das Serayu Hulu Dengan Menggunakan Model SWAT, Fakultas Geografi, Universitas Gadjah Mada, Indonesia

[2] Marhendi, Teguh, 2008. Hubungan Perubahan Tataguna Lahan Dengan Perubahan Banjir Serayu, Purwokerto

[3] Edy Junaidi dan Surya Dharma Tarigan, 2011, Pengaruh Hutan Dalam Pengaturan Tata Air dan Proses Sedimentasi Daerah Aliran Sungai (DAS), (Studi Kasus Di DAS Cisadane), Departemen Ilmu Tanah Dan Sumber Daya Lahan, Fakultas Pertanian Institut Pertanian Bogor.

[4] Marhendi, Teguh, Aji Pramono, Anggit, 2019, Prediksi Peningkatan Debit Puncak Sungai Serayu Berdasarkan Perubahan Penggunaan Lahan, Jurnal JRST, Volume 3 No. 1, Maret 2019

[5] Aji Pramono, Anggit, 2018, Analisis dan Prediksi Peningkatan Debit Puncak Di Titik Kontrol Bendung Gerak Serayu Berdasarkan Penggunaan Lahan 2011 - 2016 Kabupaten Banyumas, Skripsi, Progam Studi Teknik Sipil Universitas Muhammadiyah Purwokerto.

[6] Nuryanto, Agus, Dina S., Ina L., Jaka S., Lina K., M., Agus Nasri A., Nining P., Slamet B.,Y., 2003, Strategi Pengelolaan DAS Dalam Rangka Optimalisasi Kelestarian Sumber Daya Air. (Studi Kasus DAS Ciliwung Hulu), Makalah Kelompok 1, Institut Pertanian Bogor

[7] David L. Carr and Richard E. Bilsborrow, 2000, Population and Land Use/Cover Change: A Regional Comparasion Between Central America and South America.

[8] William B. Meyer and B. L. Turner II, 1994, Changes in Land Use and Land Cover: A Global Perspective. Australia.

[9] https://earth.google.com/web/@_ 7.38555545,109.6211111,226.52021562a,5681.76569123d,35y,0h,45t,0r/data=ClAaThJGCiUweDJIN2FhYmE5N DBjODFjZjc6MHg0MDUxNWM3MGM0Mzk2M2YwGZwoUxbPih3AIa9rxUjAZ1tAKgtXYWR1ayBNcmljYRg CIAEoAg.

[10] Nilda, 2014, Analisis Perubahan Penggunaan Lahan dan Dampaknya Terhadap Hasil Air Di Daerah Aliran Sungai Cisadane Hulu, Progam Studi Magister Ilmu Lingkungan, Universitas Udayana Denpasar.

[11] Triyantoro, Septiyan, 2019, Analisis Erosi Lahan DAS Sungai Serayu Hulu Menggunakan Model Usle, Skripsi, Progam Studi Teknik Sipil Universitas Muhammadiyah Purwokerto. 
